\title{
Pengaruh Capital Adequacy Ratio, Financing to SERAM BI Deposit Ratio, dan Kurs terhadap Return On A sset
}

\author{
Annisa Indria Irnawati*, Bambang Waluyo, Taufikul Ichsan \\ Program Studi Keuangan dan Perbankan Syariah Politeknik \\ Negeri Jakarta
}

\begin{abstract}
Purpose This study aims to examine the effect of Capital A dequacy R atio, Financing to Deposit Ratio, and exchange rates on Return On Assets in Islamic Banks for the period 2009 - 2017. M ethods- The analysis technique used is multiple linear regression with the assistance of the Program Eviews. Finding- The results showed that CAR has a positive but not significant effect, while FDR has a significant positive effect, and the exchange rate has a significant negative effect on R eturn On A ssets.
\end{abstract}

\begin{abstract}
Abstrak
Tujuan- Penelitian ini bertujuan untuk menguji pengaruh Capital Adequacy Ratio, Financing to Deposit Ratio, dan kurs terhadap Return On A sset pada Bank Syariah periode 2009 - 2017. M etodeTeknik analisis yang digunakan adalah regresi linier berganda berbantuan programEviews. Temuan- Hasil penelitian menunjukkan bahwa CAR berpengaruh positif namun tidak signifikan, sementara FDR berpengaruh positif signifikan, dan kurs berpengaruh negatif signifikan terhadap Return On A sset
\end{abstract}

Pedoman Sitasi: Irnawati, A., Waluyo, B., \& Ichsan, T. (2020). Pengaruh Capital Adequacy Ratio, Financing to Deposit Ratio, dan Kurs terhadap Return On Asset. SERAMBI: Jurnal Ekonomi M anajemen Dan Bisnis Islam, 2(3), 187 - 194

DO I: https:/ / doi.org/ 10.36407/ serambi.v2i3.241
Received 05 Sep 2020

Revised 20 Sep 2020

A ccepted 25 Sep 2020

Online first 28 Sep 2020

\section{Paper type}

R esearch paper

$\triangle$ Email Korespondensi*: indriaannisa@gmail.com

Keywords: Capital A dequacy Ratio, Financing to Deposit Ratio, Exchange rate, Return On Asset

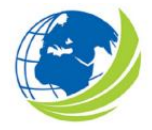

SERAMBI: Jurnal Ekonomi dan Bisnis Islam, Vol 2, N o.3, 2020, pp. 187 - 194 elSSN 2685-9904 


\section{Pendahuluan}

Dalam bidang perekonomian, industri perbankan dapat memberikan pengaruh bagi ekonomi suatu negara, khususnya pada sektor moneter. Sebagai negara yang mayoritas penduduknya muslim, dewasa ini pemerintah sedang menggencarkan kegiatan ekonomi berbasis prinsip Islam, hal ini tentunya mempengaruhi berkembangnya industri perbankan syariah.

Dalam industri perbankan, kegiatan bisnis yang berjalan dilandaskan dengan unsur kepercayaan, dan dalam memperdagangkan jasanya, bank juga hendak memperoleh keuntungan. Keuntungan tersebut diperoleh bank selama menjalankan fungsi sebagai lembaga intermediasi keuangan yang menghimpun dana dari unit ekonomi yang surplus berupa dana pihak ketiga, dan menyalurkannya pada unit ekonomi yang defisit dalam bentuk pembiayaan. Selain sebagai lembaga intermediasi keuangan, bank juga memiliki fungsi sebagai pendukung kelancaran mekanisme pembayaran, sarana investasi, dan jasa - jasa keuangan lainnya.

Sebagai lembaga yang mengandalkan unsur kepercayaan dalam operasionalnya, maka bank dituntut untuk dapat menjaga keseimbangan antara pemeliharaan likuiditas yang cukup, dengan pencapaian rentabilitas yang wajar, serta pemenuhan modal yang memadai. Dengan memperhatikan hal tersebut, maka itu artinya pihak manajemen bank telah menjaga atau bahkan meningkatkan kinerja bank, dengan demikian hal ini tentunya dapat meningkatkan profitabilitas bank. Profitabilitas merupakan indikator untuk mengukur kinerja suatu perusahaan (bank) yang diproksikan dengan Return On A sset.

Menurut Antariksa (2006) faktor yang menentukan Return On A sset terbagi menjadi faktor internal dan faktor eksternal. Faktor internal yang dapat mempengaruhi Return on Asset diantaranya adalah tingkat kecukupan modal yang diwakili oleh rasio Capital A dequacy Ratio (CAR), dan tingkat likuiditas yang diwakili oleh rasio Financing to D eposit Ratio (FDR), sedangkan faktor eksternal yang dapat mempengaruhi Return On Asset salah satunya yaitu nilai tukar rupiah. Untuk membuktikan teori - teori yang ada, dapat dilihat pada laporan keuangan PT Bank X. PT Bank X periode 2009- 2017.

Tabel 1. Data Rasio PT Bank Syariah X dan nilai tukar rupiah

\begin{tabular}{|l|l|l|l|l|}
\hline Tahun & CAR & FDR & $\begin{array}{c}\text { Nilai Tukar } \\
\text { Rupiah }\end{array}$ & ROA \\
\hline 2009 & $11.10 \%$ & $85.82 \%$ & Rp. 10.394 & $0.45 \%$ \\
\hline 2010 & $13.26 \%$ & $91.52 \%$ & Rp. 9084 & $1.36 \%$ \\
\hline 2011 & $12,01 \%$ & $85,18 \%$ & Rp. 8779 & $1,52 \%$ \\
\hline 2012 & $11,57 \%$ & $94,15 \%$ & Rp. 9.380 & $1,54 \%$ \\
\hline 2013 & $14,05 \%$ & $99,99 \%$ & Rp. 10.451 & $0,50 \%$ \\
\hline 2014 & $13,91 \%$ & $84,14 \%$ & Rp. 11.878 & $0,17 \%$ \\
\hline 2015 & $12,36 \%$ & $90,30 \%$ & Rp. 13.392 & $0,20 \%$ \\
\hline 2016 & $12,74 \%$ & $95,13 \%$ & Rp. 13.307 & $0,22 \%$ \\
\hline 2017 & $13,64 \%$ & $84,41 \%$ & Rp. 13.384 & $0,11 \%$ \\
\hline
\end{tabular}

Sumber : Website resmi Bank Indonesia

Berdasarkan data yang tertera pada Tabel 1 dapat dilihat bahwa tidak semua bukti empiris sesuai teori, dimana terjadi pergerakan pada CAR dan ROA secara fluktuatif, yang pada tahun 2011 ke 2012 terjadi penurunan pada CAR yaitu dari $12,01 \%$ menjadi $11,57 \%$, akan tetapi terjadi kenaikan pada tahun berikutnya yaitu dari 2012 ke 2013, dari 11,57\% menjadi 14,05\%. Namun terjadi kenaikan pada ROA pada tahun 2011 ke 2012 yaitu dari 1,52\% menjadi 1,54\%, dan menurun pada 2012 ke 2013 yaitu dari 1,54\% menjadi 0,50\%. Ketidaksesuaian teori dan bukti 
empiris juga terjadi pada FDR dan ROA pada tahun 2012 ke 2013, dimana FDR meningkat dari 94,15\% menjadi 99,99\%, namun ROA menurun dari 1,54\% menjadi 0,50\%. Selain itu, pada kurs 2011 ke 2012 mengalami depresiasi yaitu Rp. 8.779 per dollar AS menjadi Rp. 9.380 per dollar AS, akan tetapi pada ROA peningkatkan dari $1,52 \%$ menjadi $1,54 \%$, hal yang sama juga terulang pada tahun 2014 ke 2015 yang mana kurs kembali melemah dari Rp. 11.878 per dollar AS menjadi Rp. 13.391 per dollar AS, dan pada ROA juga terjadi kenaikan dari 0,17\% menjadi 0,20\%.

Berdasarkan latar belakang masalah yang telah dipaparkan, maka permasalahan dalam penelitian ini, yaitu adanya ketidakseuaian bukti empiris dengan teori. Maka dengan adanya ketidaksesuaian teori dengan data empiris dan perbedaan hasil dari masing - masing penelitian, maka perlu dilakukan penelitian lanjutan untuk memperoleh kepastian mengenai pengaruh CAR, FDR, dan Nilai Tukar terhadap ROA.

\section{Kajian Pustaka \\ Kinerja Keuangan}

Kinerja keuangan merupakan hal penting yang harus dicapai oleh suatu perusahaan, selain itu kinerja keuangan juga menjadi salah satu dasar penilaian kondisi keuangan, khususnya bank. Penilaian kinerja keuangan bank, dapat dilakukan berdasarkan analisis rasio keuangan yang terdapat pada laporan keuangan. Menurut Surat Edaran Otoritas Jasa Keuangan No. 10 / SEOJK.03 / 2014 tentang Penilaian Tingkat Kesehatan Bank Umum Syariah dan Unit Usaha Syariah, rasio kesehatan bank diantaranya adalah rasio permodalan yang diproksikan dengan Capital A dequacy Ratio (CAR), rasio likuiditas yang diproksikan dengan Financing to D eposit Ratio (FDR), dan rasio profitabilitas yang diproksikan dengan Return On Asset (ROA). Selain itu, faktor eksternal juga memiliki pengaruh atas pengambilan keputusan oleh manajemen bank, diantaranya yaitu kebijakan moneter, nilai tukar, inflasi, Bl rate dan inovasi instrument keuangan.

\section{Capital Adequacy Ratio}

Agar suatu bank dapat berkembang secara sehat dan mampu bersaing, maka permodalan menjadi suatu unsur yang penting untuk diperhatikan. Pentingnya perhatian terhadap besar atau kecilnya modal suatu bank dikarenakan modal bank dapat mempengaruhi tingkat kepercayaan nasabah terhadap kinerja bank. Dalam laporan keuangan, modal diproksikan dengan Capital A dequacy Ratio. Menurut Peraturan Otoritas Jasa Keuangan Nomor 21 / POJK.03 / 2014 mengenai Kewajiban Penyediaan Modal Minimum Bank Umum Syariah yang menyatakan bahwa tingkat kecukupan yang wajib dimiliki bank syariah adalah $8 \%$.

\section{Financing to Deposit Ratio}

Likuiditas adalah suatu kemampuan perusahaan dalam memenuhi kewajiban jangka pendek terhadap deposan dan kewajiban dalam memenuhi permintaan pembiayaan. Menurut Kasmir (2008:221) suatu bank dapat dikatakan likuid apabila bank tersebut mampu membayar semua hutang - hutangnya terutama hutang jangka pendek dan mampu memenuhi permintan pembiayaan nasabah. Untuk mengetahui likuid atau tidaknya suatu bank dapat dilihat dari rasio keuangan yang diproksikan dengan Financing to Deposit Ratio (FDR). Menurut Asosiasi Perbankan Syariah Indonesia (ASBISINDO) FDR yang ideal bagi suatu bank syariah adalah 80\% $90 \%$, dan terdapat batas toleransi FDR perbankan syariah sekitar $110 \%$. 
Nilai Tukar

Nilai tukar atau kurs (exchange rate) adalah harga suatu mata uang relatif terhadap mata uang negara lain (Ekananda 2014:168), atau dengan kata lain kurs merupakan perbandingan nilai tukar mata uang suatu negara dengan mata uang negara asing atau perbandingan nilai tukar valuta antar negara. Penawaran dan permintaan valuta asing timbul karena adanya hubungan internasional yang terjalin antar negara dalam perdagangan barang maupun jasa, sehingga untuk menyelesaikan transaksi antar negara perlu menukarkan mata uang dalam negeri dengan valuta asing, dan sebaliknya.

Return On A sset

Profitabilitas adalah kemampuan suatu perusahaan untuk memperoleh pendapatan diatas biaya - biaya yang telah diperhitungkan (Kuncoro, 2013). Untuk mengetahui tingkat profitabilitas suatu bank dapat digunakan perhitungan dengan rasio keuangan yaitu Return $0 \mathrm{n}$ A sset. Semakin besar Return O n A sset suatu bank, maka artinya semakin efisien penggunaan aset, sehingga akan memperbesar keuntungan bank. Return O n A sset juga dapat menjadi tolak ukur kesehatan bank, karena apabila suatu bank mengalami kerugian dalam kegiatan operasionalnya secara kontinu maka hal tersebut akan memakan modal bank, sehingga bank itu dapat dikategorikan bank yang tidak sehat.

\section{Metode Penelitian}

Jenis penelitian ini adalah asosiatif yang bertujuan untuk mencari hubungan satu variabel dengan variabel lain, dengan jenis data yang digunakan yaitu data sekunder. Populasi dalam penelitian ini adalah Bank Umum Syariah di Indonesia, dan yang digunakan sebagai sampel adalah Bank Syariah X. Teknik analisis data yang digunakan ialah regresi linier berganda dengan menggunakan aplikasi SPSS 21.

\section{Hasil dan Diskusi}

\section{Hasil}

Setelah asumsi klasik meliputi uji normalitas, heterokedastisitas, multikolinieritas dan autokorelasi dapat dipenuhi, maka interpretasi hasil regresi dijelaskan sebagai berikut:

Tabel 2. Hasil Analisis Regresi

\begin{tabular}{|c|c|c|c|l|}
\hline Variabel & Koefisien & Std.error & T-statistic & Sig \\
\hline LG10_CAR & .213 & .687 & .310 & .758 \\
\hline LG10_FDR & 4.104 & 1.418 & 2.893 & .007 \\
\hline LG10_Nilai Tukar & -5.537 & .566 & -9.782 & .000 \\
\hline F-Statistic & 45.173 & & & \\
\hline Sig(F-Test) & .000 & & & \\
\hline
\end{tabular}

Sumber: data diolah peneliti

Berdasarkan table 2 variabel bebas C apital A dequacy Ratio, Financing to D eposit Ratio, dan nilai tukar secara simultan berpengaruh terhadap R eturn O n A sset. Hal ini terlihat dari nilai $F_{\text {hitung }}$ sebesar 45,173 yang memiliki nilai lebih besar dari $F_{\text {tabel }}$ yaitu 3,28. Bukti lainnya juga terlihat pada nilai signifikansi sebesar 0,000 yang kurang dari 0,05. Maka secara bersama - sama variabel 
bebas (Capital A dequacy Ratio, Financing to D eposit Ratio, dan nilai tukar) memiliki pengaruh signifikan terhadap Return On A sset. Diperoleh persamaan regresi sebagai berikut: LG10_ROA $=13.784+0.213 L G 10 \_C A R+4.104 L G 10 \_F D R-5.537 L G 10 \_N i l a i$ Tukar

Nilai konstanta berada pada posisi 13.784 yang menunjukkan bahwa terdapat pengaruh pada Capital A dequacy Ratio, Financing to D eposit Ratio, dan Nilai Tukar Rupiah terhadap Return On A sset. Nilai koefisien regresi Capital A dequacy Ratio $\left(X_{1}\right)$ sebesar 0,213 menunjukkan besarnya pengaruh Capital Adequacy Ratio terhadap Return On Asset Bank Syariah $\mathrm{X}$ bernilai positif. Artinya jika variabel bebas (Capital A dequacy $R$ atio) mengalami peningkatan $1 \%$, maka Return $0 \mathrm{n}$ A sset akan mengalami kenaikan sebesar $0,213 \%$ dengan asumsi variabel lain dalam keadaan konstan. Nilai koefisien regresi Financing to Deposit Ratio $\left(X_{2}\right)$ sebesar 4,104 menunjukkan besarnya pengaruh Financing to $D$ eposit Ratio terhadap Return On A sset Bank Syariah X bernilai positif. Artinya jika variabel bebas (Financing to $D$ eposit $R$ atio) mengalami peningkatan $1 \%$, maka Return On Asset akan mengalami kenaikan sebesar 4,104\% dengan asumsi variabel lain dalam keadaan konstan.

Nilai koefisien regresi Nilai Tukar $\left(X_{3}\right)$ sebesar 5,537 dan bernilai negatif. Hal ini menunjukkan bahwa adanya pengaruh tidak searah antara nilai tukar terhadap Return O n A sset. Maka dapat diartikan bahwa jika variabel bebas (nilai tukar) mengalami kenaikan 1\%, maka akan menyebabkan penurunan pada Return On Asset sebesar 5,537\% dengan asumsi variabel lain dalam keadaan konstan. Dapat dijabarkan hubungan masing - masing variabel bebas terhadap variabel terikat. Berikut penjelasannya:

Berdasarkan output uji data, variabel Capital Adequacy Ratio tidak memiliki pengaruh terhadap Return On Asset. Hal ini dapat dilihat bahwa nilai signifikansi Capital A dequacy Ratio yaitu 0,758 lebih besar dari 0,05. Sedangkan nilai thitung Capital A dequacy Ratio sebesar 0,310 yang kurang dari $\mathrm{t}_{\text {tabel }}$ yaitu 2,037. Maka dapat disimpulkan bahwa $\mathrm{H}_{\circ}$ diterima dan $\mathrm{H}_{1}$ ditolak.

Variabel Financing to D eposit Ratio memiliki pengaruh terhadap Return On Asset. Hal ini dapat dilihat bahwa berdasarkan output uji data nilai signifikansi Financing to Deposit Ratio sebesar 0,007 yang kurang dari 0,05. Nilai thitung Financing to D eposit Ratio sebesar 2,893 lebih besar dari $\mathrm{t}_{\text {tabe }}$ yaitu senilai 2,037. Maka dapat disimpulkan bahwa $\mathrm{H}_{\circ}$ ditolak dan $\mathrm{H}_{1}$ diterima.

Variabel nilai tukar memiliki pengaruh negatif terhadap Return On Asset. Hal ini dapat dilihat dari hasil uji data, yang mana variabel nilai tukar memiliki nilai signifikansi sebesar 0,000 yang kurang dari 0,05, dan nilai thitung yaitu 9,782 yang lebih besar dari tabel senilai 2,037. Adanya nilai negatif pada thitung dapat diartikan bahwa terdapat hubungan yang berbanding terbalik antara nilai tukar dengan Return O n A sset.

\section{Pembahasan}

Pengaruh Capital A dequacy Ratio terhadap Return O n A sset

Berdasarkan hasil penelitian yang dilakukan secara parsial Capital A dequacy Ratio tidak berpengaruh signifikan terhadap Return On A sset Bank Syariah X. Hal ini dapat diartikan bahwa tinggi atau rendahnya Capital A dequacy Ratio suatu bank belum tentu mempengaruhi Return $0 \mathrm{n}$ Asset, karena dalam menjalankan kegiatan operasional, Bank Syariah X memiliki beban operasional yang harus ditanggung, namun dalam memenuhi beban operasional, Bank Syariah X kurang efisien, sehingga modal yang ada tidak berpengaruh pada Return On Asset. Hasil penelitian ini sesuai dengan penelitian yang dilakukan Fajari dan Sunarto (2017), Wibowo dan Syaichu (2013), serta Bachri,dkk (2013). 
Pengaruh Financing to D eposit Ratio terhadap Return O n A sset

Berdasarkan uji data yang telah dilakukan secara parsial, variabel Financing to D eposit Ratio memiliki pengaruh signifikan terhadap Return On Asset. Hal ini dapat diartikan bahwa dalam menjalankan peranan sebagai intermediasi keuangan, Bank Syariah $X$ mampu menghimpun dana dan mampu mengembalikan dana nasabah ketika dilakukan penarikan oleh nasabah, dan Bank Syariah X telah menyalurkan pembiayaan secara efektif dengan pengembalian yang baik, sehingga tidak ada dana menganggur dan dana yang dihimpun dapat menghasilkan peningkatan laba. Hasil penelitian ini didukung oleh penelitian yang pernah dilakukan oleh Prasanjaya dan Ramantha (2013) dan Usman Harun (2016).

Pengaruh N ilai Tukar terhadap Return On Asset

Berdasarkan uji data secara parsial, variabel nilai tukar memiliki pengaruh negatif dan signifikan terhadap Return On A sset. Hal ini dapat diartikan bahwa apabila nilai tukar rupiah mengalami depresiasi atau apresiasi, maka akan berpengaruh terhadap kewajiban val as bank pada saat jatuh tempo. Untuk kasus dalam penelitian ini, bank terindikasi memiliki kesulitan dalam memenuhi kewajiban valas, hal ini disebabkan dari melemahnya nilai rupiah terhadap dollar AS, sehingga hal inilah yang menjadi penyebab terjadinya penurunan profitabilitas yang diperoleh bank. Hasil penelitian ini sejalan dengan penelitian yang dilakukan oleh Swandayani dan Kusumaningtias (2012).

Pengaruh Capital A dequacy Ratio, Financing to D eposit Ratio, dan N ilai Tukar terhadap Return O n A sset Berdasarkan hasil uji F, Capital A dequacy Ratio, Financing to D eposit Ratio, dan nilai tukar secara simultan memiliki pengaruh terhadap Return 0 n A sset. Jika ditinjau dari hasil analisis koefisien determinasi, nilai korelasi (R) yang ada sebesar 0,899 atau 89,9\% yang artinya Capital A dequacy Ratio, Financing to $D$ eposit Ratio, dan nilai tukar dengan Return O n A sset memiliki hubungan yang kuat karena berada di atas 0,5 atau 50\%. Nilai A djusted R Square pada penelitian ini sebesar 0,791 atau $79,1 \%$ yang artinya $79,1 \%$ pengaruh terhadap Return 0 n A sset dapat dijelaskan oleh Capital Adequacy Ratio, Financing to Deposit Ratio, dan nilai tukar. Namun, sisanya sebesar $20,9 \%$ dijelaskan oleh variabel lain yang tidak terdapat dalam penelitian ini.

\section{Kesimpulan}

Capital A dequacy Ratio tidak berpengaruh signifikan terhadap Return On A sset pada Bank Syariah X periode 2009 - 2017. Hal ini disebabkan beban operasional yang ditanggung, dan Bank Syariah $X$ kurang efisien dalam mengelola dana. Financing to Deposit Ratio berpengaruh signifikan terhadap Return On A sset pada Bank Syariah X periode 2009 - 2017. Adanya hasil penelitian ini menunjukkan bahwa kinerja likuiditas dari Bank Syariah $\mathrm{X}$ ini perlu dipertahankan, karena penting bagi bank untuk mampu menghimpun dana dari nasabah dalam bentuk DPK (Dana Pihak Ketiga) dan menyalurkannya dalam bentuk pembiayaan. Nilai tukar berpengaruh negatif signifikan pada Return On A sset Bank Syariah X periode 2009 - 2017. Hal ini mengindikasikan bahwa bank mengalami kesulitan dalam memenuhi kewajiban valas yang disebabkan oleh adanya fluktuasi nilai rupiah yang semakin melemah terhadap dollar AS. Sehingga untuk melindungi bank dari risiko fluktuasi nilai tukar, perlu dilakukan lindung nilai syariah atau hedging syariah untuk membantu nilai rupiah agar lebih stabil.

Saran untuk penelitian selanjutnya : (1). Menambah jumlah sampel penelitian yang tidak hanya terbatas pada bank umum syariah yang ada dilndonesia, melainkan dapat menambahkan jenis bank lainnya seperti bank pembangunan daerah (BPD), bank konvensional, BPRS dan yang 
lainnya yang terdaftar di Bank Indonesia dan atau Otoritas Jasa Keuangan. (2). Menambah jumlah tahun periode penelitian tidak hanya 5 tahun saja. (3). Menggunakan variabel kesehatan bank lainnya dan juga menambah dengan variabel makro ekonomi, sehingga akan diperoleh gambaran perbandingan yang lebih baik tentang kondisi perbankan nasional serta usahanya dalam memenuhi rentangan nilai Return on asset optimal yang telah ditentukan oleh Bank Indonesia. (4). Penelitian mendatang dapat mempertimbangkan untuk menggunakan variabel moderating untuk mengetahui perbandingan antara variabel intervening dalam penelitian selanjutnya.

\section{Daftar Pustaka}

Antariksa, R. (2006). Pengaruh Rasio Likuiditas Terhadap Profitabilitas (Studi Kasus Pada PT Muamalat Indonesia, Tbk). Jurnal Ekonomi Keuangan dan Bisnis Islami Vol. 2 No. 2

Dendawijaya, L. (2005). M anajemen Perbankan. Edisi Kedua, Jakarta: Ghalia Indonesia.

Dwijayanti, F., dan Naomi, P. (2009). Analisis Pegaruh Inflasi, Bl Rate, Dan Nilai Tukar Uang Terhadap Profitabilitas Bank Periode 2003 - 2007. Karisma Vol. 3 (2). Jakarta: Universitas Paramadina.

Ekananda, M. (2014). Ekonomi Internasional . Jakarta: Erlangga.

Fakhruddin, I., dan Purwanti, T. (2015). Pengaruh Rasio Kesehatan Bank Terhadap Kinerja Keuangan Bank Syariah Periode 2010 - 2013. KO M PA RTEM EN Vol. XII No. 2.

Ghozali, I. (2013). A plikasi A nalisis M ultivariate dengan Program SPSS. Semarang: Badan Penerbit Universitas Diponegoro

Hasibuan, M.S.P. (2001). D asar - D asar Perbankan. Jakarta: Bumi Aksara.

Karim, A .A . (2008). Ekonomi M akro Islam. Jakarta: PT Raja Grafindo Persada.

Kasmir. (2008). Bank dan Lembaga Keuangan Lainnya. Jakarta: PT Raja Grafindo Persada.

Sugiyono. (2009). M etode Penelitian. Bandung: Alfabeta.

\section{A bout Authors}

A nnisa Indria Irnawati, Bambang Waluyo, dan Taufikul Ichsan. adalah mahasiswa dan dosen di Program Studi Keuangan dan Perbankan Syariah, Politeknik Negeri Jakarta. Penulis dapat dihubungi di Email: indriaannisa@gmail.com, bamwaluyo@yahoo.co.id, asadeltrv@gmail.com 
SERAMBI: Jurnal Ekonomi Manajemen dan Bisnis Islam Published by LPMP Imperium

Accepted author version posted online: 28 September 2020

(c) (1)

(C) 2020 The Author(s). This open access article is distributed under a Creative Commons Attribution (CC-BY) 4.0 license 